\title{
STUDY HABIT OF HIGHER SECONDARY SCHOOL STUDENTS IN RELATION TO CERTAIN VARIABLES
}

\author{
Ms. Bhavna P.Shah \\ Dr. A. J. Bharvad
}

\section{INTRODUCTION}

Study Habit plays a vital role in career development. Contemporary researches depict that the way an individual perceives shapes his career patterns. Study Habit has a significant role in developing an individual. A detailed knowledge about the nature and relation of study habit with other related factors is likely to provide an objective and encouraging basis for the society which could be very enriching and useful. In today's competing world education needs to fulfil and meet the requirements of society. Education that aims at the overall development of a child or an individual should be imparted in a way that the individual is able to face the challenges of life and is able to solve the emerging problems of life with courage.

The knowledge of relationship between study habit with respect to the psychological, personal and scholastic variables would enhance the development of scientific creativity as required. The knowledge of this relationship will certainly enhance study habit amongst the high school students. It will work as a guide to the teachers, parents, schools and society striving for the enhancement of scientific creativity. Further this knowledge would lead to the better performance of the learner and his development and thus the development of society, state and Nation.

In present research researcher has selected to study the Study Habit of high school students in relation to certain variables as a research problem.

\section{LITERATURE REVIEW}

Study habits is the habitual practices one uses to help them study and learn. Good study habits can help students achieve and/or maintain good grades.

Good study habits lead to good academic record and bad study-habits lead to poor academic record as there is direct relationship between study habits and academic achievement. Study habits play an important role in human performance in academic field (Verma, 1996; Verma \& Kumar, 1999; Satapathy \& Singhal,2000; Vyas,2002).

Ramamurti (1993) has rightly emphasized that despite possessing good intelligence and personality, the absence of good study habits hampers academic achievement. Hence, study habits of students' plays important role in learning and fundamental to school success. 


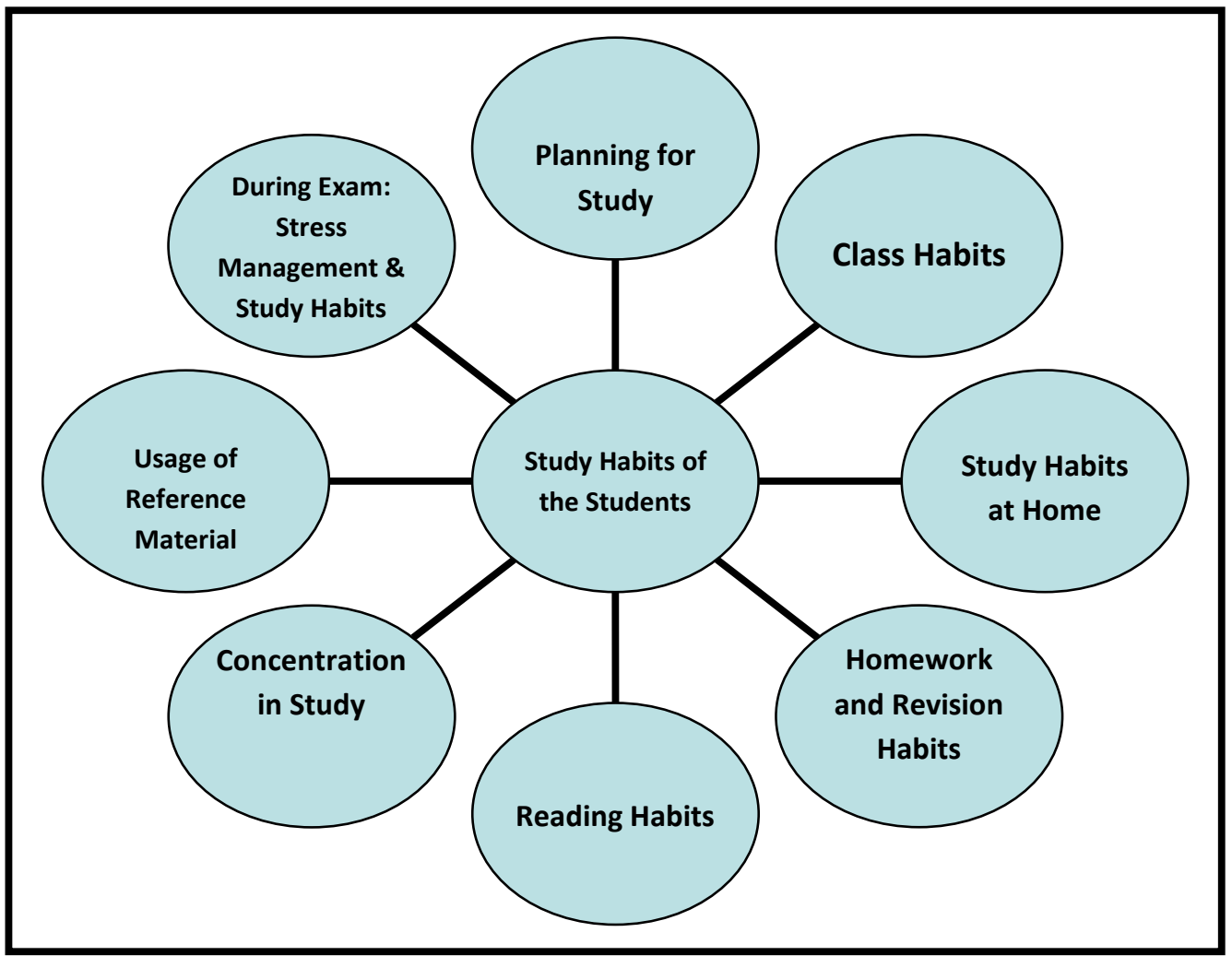

For the study total eight dimension of study habit has been identified

1. Planning of the Study: The dimension study, how students allocate time to different subject, and assign the preference for the subject. Also it tries to understand, how students prepared the syllabus.

2. In class Habits: The dimension studied in class study habits of the student. It address the question like how students solve their doubt in the class, how they concentrate and do they participate in class or not etc.

3. Study habits at Home: The dimension addresses students study habits at home. It covers dimension like time table preparation for home study, preparation of the topic before the class, Assigning importance to certain subject preparation and taking help of family members.

4. Homework and Revision Habits: The dimension addresses how students do their homework and revision of class. The dimension studies when the students do the homework, what are the problem they face while completing homework and revision, how they enjoy doing homework/revision and are they enjoy doing homework.

5. Reading Habits: The dimension addresses, how students read/ study. They read speaking loud, or by walking or by watching TV. The dimension also covers issue, related to remembering the topic. How much time students have to read to remember the topic and time of reading is also covered in the dimension.

6. Concentration in the Study: The dimension addresses the concentration problem of students while doing study. It tries identify, whether students could be concentrate in the study and for how much time. It also identify, variable creation distraction in the study like family members, TV, Friends, and Hobbies etc.

7. Usage of Reference Material: The dimension of study identify types and usage of reference material used by students for study. It also tries to find, from where they access the reference material and reasons for using reference material. 
8. Exam stress Management and study Habits: The dimension addresses study habits of students during the exam time. Aspects like time of study, stress management, collaborative study \& method of study is covered.

Based on the above eight dimension, the study was planned and executed.

\section{STATEMENT OF THE PROBLEM \& OBJECTIVE OF THE RESEARCH}

The study has been conducted to know the Study Habit of Higher Secondary School students of standard $11^{\text {th }}$ in context to various variables like gender, types of school, medium of instruction, and geographical area.

The objectives of the present study are as under:

- To identify Study Habits of the students studying in higher secondary schools of five district of Gujarat.

- To study the effect of gender on the Study Habit of the students of higher Secondary Schools of five district of Gujarat.

- To study the effect of stream (Commerce/Science) on the Study Habit of the students of Higher Secondary Schools of five district of Gujarat.

- To study the effect of geographic area (Rural/Urban) on the Study Habit of the students of higher Secondary schools of five district of Gujarat.

\section{HYPOTHESIS OF THE STUDY}

The null hypotheses formed by researcher are as follows:

1. Ho1: There is no significant difference between mean score of Boys and Girls of Higher Secondary School on Study Habit scale.

2. Ho2: There is no significant difference between mean score of students studying in rural and urban area on Higher Secondary School on Study Habit scale.

3. Ho3: There is no significant difference between mean score of high school students of Science and Commerce Stream on Study Habit scale.

\section{RESEARCH VARIABLES}

Variables are the conditions or characteristic that the experiment manipulators controls or observes. In present study the following variables were selected

$\underline{\text { Table - } 1}$ Table showing types of variable and its level

\begin{tabular}{|l|l|l|l|}
\hline $\begin{array}{c}\text { Sr. } \\
\text { No. }\end{array}$ & Types of variables & \multicolumn{1}{|c|}{ Variables } & \multicolumn{1}{|c|}{ Level } \\
\hline 1 & Independent & Gender & $\begin{array}{l}\text { 1. Boys } \\
2 . \text { Girls }\end{array}$ \\
\hline 2 & Independent & Geographical Area & $\begin{array}{l}\text { 1. Rural } \\
\text { 2. Urban }\end{array}$ \\
\hline 3 & Independent & Stream & $\begin{array}{l}\text { 1. Commerce } \\
\text { 2. Science }\end{array}$ \\
\hline 4 & Dependent & Study Habit & \multicolumn{2}{|c|}{} \\
\hline
\end{tabular}




\section{RESEARCH METHODOLOGY}

In the present research researcher have studied the study habit of grade 11 students thus the method of research is survey method.

- Sample Size \& Sampling Method: Total sample size of the research is 1008 students of 11 grade selected from five districts of Gujarat. Sample size determine using Taro Yamen's Formula for sample size calculation. Stratified random sampling has been used as sampling method. Respondents are selected from Ahmedabad, Mehsana, Rajkot, Kutch/Bhuj and Surat district of Gujarat.

- Research Instruments: In present research researcher has used standardise Study Habit Inventory prepared by Bhavna Shah under the guidance of Dr. A. J. Bharwad. The reliability of the tool by test retest method was $0.91 \&$ by spilt half method 0.71 . The congruent validity of test is 0.69 .

- Data Collection: The research used standardised study habit inventory which was designed by researcher for data collection. The researcher first collected the information and list of the all the Higher Secondary schools of five district from website. With prior permission of the principal the researcher went to schools and gave test to the students and thus collected data.

- Analysis of Data: Researcher has classified and interpreted data by Frequency Distribution. The data was analysed by statistical techniques like Mean, Median, Standard Deviation, ANOVA, Chi Square and Factor Analysis. Total 8 Dimension of Study habits of the students are studied in detail. These dimensions are planning for study, in class habits, study habits at home, homework and revision habits, reading habits, concentration in study, Usage of reference material and during the exam study habits. Total 35 Variable in all this eight dimension has been identified.

\section{MAJOR FINDING OF THE STUDY}

\begin{tabular}{|l|l|l|c|c|}
\hline $\begin{array}{l}\text { Sr. } \\
\text { No. }\end{array}$ & Hypothesis & ANOVA & Significant level & Rejected/Accepted \\
\hline 1 & $\mathrm{Ho}_{1}$ & Annexure 1 & 0.05 & Accepted \\
\hline 2 & $\mathrm{Ho}_{2}$ & Annexure 2 & 0.05 & Accepted \\
\hline 3 & $\mathrm{Ho}_{3}$ & Annexure 3 & 0.05 & Rejected \\
\hline
\end{tabular}

The following are the major findings of this study

- The study habits of Girls \& Boys found similar in nature in 6 out of 8 component. Major variation found in "during exam preparation/ Stress Management" and "Concentration in the study". Study habits found significantly different with respect to these two dimensions.

- The Study habits of rural and urban area students of the cities found similar in 6 dimension of habits. Variation found in terms of planning for the study, Exam preparation/ stress management \& usage of reference material.

- The study habits of Science \& Commerce Students of Higher Secondary school found significantly different in nature in 5 out of 8 component. Similarity in their habits founds only in planning for the study \& concentration in the study dimension. 


\section{EDUCATIONAL IMPLICATIONS}

Future of India is constructed in class room. For creating better future for India, it is necessary to address present problem of education system, teaching methodology, teacher's intention, study habits of students, frustration in students, academic achievement, problems of the students and problem of self-efficacy in the students.

The finding of the study can be used:

- To consult the students and mentoring their progress

- Pedagogy and teaching method in the school can be designed keeping in mind the study habits of the students

- Good study habits of the students can be encouraged, and negative habits can be controlled by taking help of parents and teacher.

- From the study, it was found that, students in rural area don't use reference material. The reason for same is non availability of library and book stores. NGO, Society and Government should work in providing reference material to the students of rural area.

\section{Limitations of the Study:}

The following are the limitations of the study:

- The research was limited to the students of five district of Gujarat.

- The present research was limited to the students of standard 11 of Higher Secondary school.

- Data collection was done in the year academic year 2017-18.

- The present research was limited to the students of GSEB only

\section{Suggestions for future Research}

- The research can be further extended to study the implication of study habits on academic achievement, frustration, stress management and self-efficacy.

- The research can be conducted in other states of the country, to study the study habits of the students. It will help in identifying impact of culture on study habits.

\section{Conclusion:}

The research describes 8 dimension of study habits $\&$ explain this 8 dimension with the help of $35 \mathrm{sub}$ variables. From the present research we can conclude that impact of Gender and Area is not significant on study habits of the student of Higher Secondary School. The research also conclude that study habits of students of different stream is significantly different. It means science and commerce student have different types of study habits. 


\section{Bibliography}

1. Adam P. Heath, Don Scott, (1998), The Study Habitand image congruence hypothesis: An empirical evaluation in the motor vehicle market", European Journal of $1110-1123$

2. Agarwal, Y. P. (1988) Research in Emerging Fields of Education New Delhi: SterlingPublication Private Ltd.

3. Agarwal Dinesh (1998) A Study of the Study Habit of the Adolescents, and its Relationship with Scholastic Achievement and Adjustment, Ph.D. Education, Aligarh University

4. Best, John W. (1977) Research in Education New Delhi: Prentice-Hall of India (Pvt.) Ltd.

5. Bharth G., A (1994) study of Study Habit and Achievement Motivation of early adolescents Ph.D. Psy., Osmania University

6. Bhattacharya Swaha (2000) Study Habit and Achievement Motivation of Hearing Impaired and Normal Adolescents A Comparative Study. Dept. of Applied Psycho, University of Calcutta.

7. Borg, Walter R. and Gall, M. R. (1987) Educational / Research :An Introduction (Fifth Edition) New York: Longman

8. Chapin, F. S. (1955) Experimental Designs in Sociological Research Revised Edition. New York : Harper

9. Cochran, W.G.(1974) Sampling Techniques New Delhi: Wiley Eastern Private Ltd.

10. Cohen, L. and Manion L. (1985) Research Methods in Education (Second Edition). London : Groom Helm.

11. Corey, S.M. (1953) Action Research to Improve School Practices New York: Bureau of Publications, Teachers College, Columbia University.

12. Good, Carter V. (1959) Dictionary of Education (Second Edition). New York : McGrawHill Book Co.

13. Gorden, R.L. (1975). Interviewing Strategy, Techniques and Tactics Homewood. 1linois: Dorsey Press.

14. Travers R. M. W. (1973) Second Handbook of Research on Teaching chicago: Rand McNally Co.

15. Van Dalen, D. B. (1979) Understanding Educational Research (Third Edition) New York: McGraw-Hill

16. Verma, M. (1965) An Introduction to Educational and Psychological Research Bombay: Vikas Publishing House

17. Whitney, Frederick L. (1960) The Elements of Research Third Edition. New York: Prentice-Hall 

Shah \& Dr. A.J. Bharvad / Page 63-71

Annexure: 1

\begin{tabular}{|c|c|c|c|c|}
\hline \multicolumn{5}{|c|}{ Gender Base Analysis (ANOVA) } \\
\hline Var No. & Ratio & Sig & Alpha Value & HO Accepted or Rejected \\
\hline \multicolumn{5}{|c|}{ Planning for Study } \\
\hline 1 & 3.512 & .061 & 0.05 & Accept \\
\hline 2 & .627 & .429 & 0.05 & Accept \\
\hline 3 & 1.127 & .289 & 0.05 & Accept \\
\hline \multicolumn{5}{|c|}{ In Class Habits } \\
\hline 4 & .180 & .671 & 0.05 & Accept \\
\hline 5 & .209 & .648 & 0.05 & Accept \\
\hline 6 & .576 & .448 & 0.05 & Accept \\
\hline 7 & .056 & .813 & 0.05 & Accept \\
\hline \multicolumn{5}{|c|}{ Study Habits at Home } \\
\hline 8 & 11.142 & .001 & 0.05 & Reject \\
\hline 9 & .000 & .989 & 0.05 & Accept \\
\hline 10 & 11.303 & .001 & 0.05 & Reject \\
\hline 11 & .288 & .591 & 0.05 & Accept \\
\hline \multicolumn{5}{|c|}{ Homework and Revision Habits } \\
\hline 12 & .071 & .789 & 0.05 & Accept \\
\hline 13 & 1.686 & .194 & 0.05 & Accept \\
\hline 14 & 9.597 & .002 & 0.05 & Reject \\
\hline 15 & 2.832 & .093 & 0.05 & Accept \\
\hline \multicolumn{5}{|c|}{ Reading Habits } \\
\hline 16 & 5.422 & .020 & 0.05 & Reject \\
\hline 17 & .099 & .753 & 0.05 & Accept \\
\hline 18 & .930 & .335 & 0.05 & Accept \\
\hline 19 & 9.512 & .002 & 0.05 & Reject \\
\hline 20 & .736 & .391 & 0.05 & Accept \\
\hline 21 & 7.041 & .008 & 0.05 & Reject \\
\hline \multicolumn{5}{|c|}{ Concentration in Study } \\
\hline 22 & 0.018 & 0.892 & 0.05 & Accept \\
\hline 23 & 8.975 & 0.003 & 0.05 & Reject \\
\hline 24 & 4.497 & 0.034 & 0.05 & Reject \\
\hline 25 & 28.389 & 0 & 0.05 & Reject \\
\hline \multicolumn{5}{|c|}{ Usage of Reference Material } \\
\hline 26 & 0.033 & 0.857 & 0.05 & Accept \\
\hline 27 & 0.435 & 0.51 & 0.05 & Accept \\
\hline 28 & 0.519 & 0.471 & 0.05 & Accept \\
\hline 29 & 1.678 & 0.196 & 0.05 & Accept \\
\hline \multicolumn{5}{|c|}{ During Exam : Stress Management and Study Habits } \\
\hline 30 & 6.445 & 0.011 & 0.05 & Reject \\
\hline 31 & 0.161 & 0.688 & 0.05 & Accept \\
\hline 32 & 0.129 & 0.719 & 0.05 & Accept \\
\hline 33 & 15.247 & 0 & 0.05 & Reject \\
\hline 34 & 19.65 & 0 & 0.05 & Reject \\
\hline 35 & 10.609 & 0.001 & 0.05 & Reject \\
\hline
\end{tabular}

\section{Annexure-2}

\begin{tabular}{|c|c|c|c|c|}
\hline \multicolumn{5}{|c|}{ Rural and Urban Area wise Analysis (ANOVA) } \\
\hline Var No. & F Ratio & Sig & Alpha Value & HO Accepted or Rejected \\
\hline \multicolumn{5}{|c|}{ Planning for Study } \\
\hline 1 & .081 & .776 & 0.05 & Accept \\
\hline 2 & 7.103 & .008 & 0.05 & Reject \\
\hline 3 & 12.760 & .000 & 0.05 & Reject \\
\hline \multicolumn{5}{|c|}{ In Class Habits } \\
\hline 4 & 3.793 & .052 & 0.05 & Accept \\
\hline 5 & 3.131 & .077 & 0.05 & Accept \\
\hline 6 & 1.532 & .216 & 0.05 & Accept \\
\hline 7 & 2.887 & .090 & 0.05 & Accept \\
\hline \multicolumn{5}{|c|}{ Study Habits at Home } \\
\hline 8 & 7.907 & .005 & 0.05 & Accept \\
\hline 9 & .172 & .678 & 0.05 & Accept \\
\hline 10 & 2.483 & .115 & 0.05 & Accept \\
\hline 11 & 1.154 & .283 & 0.05 & Accept \\
\hline \multicolumn{5}{|c|}{ Homework and Revision Habits } \\
\hline 12 & 2.962 & .086 & 0.05 & Accept \\
\hline 13 & 1.554 & .213 & 0.05 & Accept \\
\hline 14 & .986 & .321 & 0.05 & Accept \\
\hline 15 & .282 & .595 & 0.05 & Accept \\
\hline \multicolumn{5}{|c|}{ Reading Habits } \\
\hline 16 & 2.411 & .121 & 0.05 & Accept \\
\hline 17 & .167 & .683 & 0.05 & Accept \\
\hline 18 & .001 & .977 & 0.05 & Accept \\
\hline 19 & 7.361 & .007 & 0.05 & Accept \\
\hline 20 & 5.442 & .020 & 0.05 & Accept \\
\hline 21 & 2.137 & .144 & 0.05 & Accept \\
\hline \multicolumn{5}{|c|}{ Concentration in Study } \\
\hline 22 & 3.804 & .051 & 0.05 & Accept \\
\hline 23 & 1.710 & .191 & 0.05 & Accept \\
\hline 24 & 15.124 & .000 & 0.05 & Reject \\
\hline 25 & 10.078 & .002 & 0.05 & Reject \\
\hline \multicolumn{5}{|c|}{ Usage of Reference Material } \\
\hline 26 & 1.279 & .258 & 0.05 & Accept \\
\hline 27 & 19.014 & .000 & 0.05 & Reject \\
\hline 28 & 1.544 & 214 & 0.05 & Accept \\
\hline 29 & 14.589 & .000 & 0.05 & Reject \\
\hline \multicolumn{5}{|c|}{ During Exam : Stress Management and Study Habits } \\
\hline 30 & 1.482 & .224 & 0.05 & Accept \\
\hline 31 & .263 & .608 & 0.05 & Accept \\
\hline 32 & 8.432 & .004 & 0.05 & Reject \\
\hline 33 & 10.069 & .002 & 0.05 & Reject \\
\hline 34 & .825 & .364 & 0.05 & Accept \\
\hline 35 & .509 & .476 & 0.05 & Accept \\
\hline
\end{tabular}


Towards Excellence: An Indexed, Refereed \& Peer Reviewed Journal of Higher Education / Ms. Bhavna Shah \& Dr. A.J. Bharvad / Page 63-71

Annexure 3

\begin{tabular}{|c|c|c|c|c|}
\hline \multicolumn{5}{|c|}{ Stream Base Analysis (ANOVA) } \\
\hline Var No. & Ratio & & Alpha Value & Ho Accepted or Rejected \\
\hline \multicolumn{5}{|c|}{ Planning for Study } \\
\hline 1 & 1.530 & .216 & 0.05 & Accept \\
\hline 2 & 29.273 & .000 & 0.05 & Reject \\
\hline 3 & .610 & .435 & 0.05 & Accept \\
\hline \multicolumn{5}{|c|}{ In Class Habits } \\
\hline 4 & 18.252 & .000 & 0.05 & Reject \\
\hline 5 & 2.562 & .110 & 0.05 & Accept \\
\hline 6 & .098 & .755 & 0.05 & Accept \\
\hline 7 & 6.489 & .011 & 0.05 & Reject \\
\hline \multicolumn{5}{|c|}{ Study Habits at Home } \\
\hline 8 & 21.153 & .000 & 0.05 & Reject \\
\hline 9 & 2.658 & .103 & 0.05 & Accept \\
\hline 10 & 6.355 & .012 & 0.05 & Reject \\
\hline 11 & 7.068 & .008 & 0.05 & Reject \\
\hline \multicolumn{5}{|c|}{ Homework and Revision Habits } \\
\hline 12 & 3.849 & .050 & 0.05 & Reject \\
\hline 13 & 5.540 & .019 & 0.05 & Reject \\
\hline 14 & 1.575 & .210 & 0.05 & Accept \\
\hline 15 & 9.652 & .002 & 0.05 & Reject \\
\hline \multicolumn{5}{|c|}{ Reading Habits } \\
\hline 16 & 3.898 & .049 & 0.05 & Reject \\
\hline 17 & 5.579 & .018 & 0.05 & Reject \\
\hline 18 & .757 & .384 & 0.05 & Accept \\
\hline 19 & 30.510 & .000 & 0.05 & Reject \\
\hline 20 & 28.819 & .000 & 0.05 & Reject \\
\hline 21 & 2.561 & .110 & 0.05 & Accept \\
\hline \multicolumn{5}{|c|}{ Concentration in Study } \\
\hline 22 & 40.492 & .000 & 0.05 & Reject \\
\hline 23 & .000 & .997 & 0.05 & Accept \\
\hline 24 & 1.892 & .169 & 0.05 & Accept \\
\hline 25 & .056 & .813 & 0.05 & Accept \\
\hline \multicolumn{5}{|c|}{ Usage of Reference Material } \\
\hline 26 & 6.909 & .009 & 0.05 & Reject \\
\hline 27 & 20.559 & .000 & 0.05 & Reject \\
\hline 28 & 2.306 & .129 & 0.05 & Accept \\
\hline 29 & 4.892 & .027 & 0.05 & Reject \\
\hline \multicolumn{5}{|c|}{ During Exam : Stress Management and Study Habits } \\
\hline 30 & .042 & .839 & 0.05 & Accept \\
\hline 31 & 5.735 & .017 & 0.05 & Reject \\
\hline 32 & 8.274 & .004 & 0.05 & Reject \\
\hline 33 & 11.317 & .001 & 0.05 & Reject \\
\hline 34 & 39.749 & .000 & 0.05 & Reject \\
\hline 35 & 2.257 & .133 & 0.05 & Accept \\
\hline
\end{tabular}

Annexure 4 Variable of Study

\begin{tabular}{|c|}
\hline Planning for Study \\
\hline 1. Difficult Subject Time allocation \\
\hline 2. Distribution of Time for Different Subject \\
\hline 3. Important Question preparation \\
\hline In Class Habits \\
\hline 4. I don't like to answer the question of faculty \\
\hline 5. Ask help from teacher for the doubt emerge in the class discussion \\
\hline 6. In class, I don't concentrate on subject I don't like \\
\hline 7. In class, in case of Doubt I feel hesitate to ask to faculty \\
\hline Study Habits at Home \\
\hline 8. I Study as per the the Time Table \\
\hline 9. Prepare the topic in advance before it discuss in the class \\
\hline 10. In study at home I don't take help from family members \\
\hline 11. Spend more time for Science and Maths Subject \\
\hline Homework and Revision Habits \\
\hline 12. After coming home directly I Don't wish to do home work \\
\hline 13. Due to responsibilty at home can not complete homework \\
\hline 14. Due to TV watching, could not complete home work \\
\hline 15. I don't enjoy doing home work received from School \\
\hline Reading Habits \\
\hline 16. I study speaking Loud \\
\hline 17. I study while watching TV \\
\hline 18. I study by walking \\
\hline 19. I could not remember till I study it more number of time \\
\hline 20. I don't decide in advance about study time \\
\hline 21. if I could not remember that I read again and again \\
\hline Concentration in Study \\
\hline 22. I could not concetrate in the study for more than $1 \mathrm{hr}$ \\
\hline 23. I could no Concetrate continuosly while reading \\
\hline 24. Because of Entry and Exit and Noise outside disturb my concentration \\
\hline 25. To spend time on hobbies, avoid study \\
\hline Usage of Reference Material \\
\hline 26. Using Encylopedia or disctionary for the new word coming in study \\
\hline 27. Using reference book for study and preparation \\
\hline 28. For reference book, visiting library of school regularly \\
\hline 29. Uses internet for getting more understanding about the topic \\
\hline During Exam : Stress Management and Study Habits \\
\hline 30. I don't like to study during night at the time of Exam \\
\hline 31. I don't study with an intention to pass in the exam \\
\hline 32. I don't do study discussion with my friend during exam \\
\hline 33. During exam I get important Question. Therefore I Study them only \\
\hline 34. I mug up important question for exam \\
\hline 35. During exam, what ever I read, I could not remember it \\
\hline
\end{tabular}




\section{Researcher,}

Bhavna P.Shah

Email:profbhavnashah@gmail.com

M- 9725533799

3

\section{Guide,}

\& Dr. A. J. Bharvad

Professor, Department of Education,

Gujarat University 